\title{
Occurrence and Properties of Proteases in Plant Latices
}

Author

Affiliation
André Domsalla, Matthias F. Melzig

Institute of Pharmacy, Free University Berlin, Berlin, Germany
Key words

$\checkmark$ protease

$\checkmark$ plant

- latex

- cysteine endopeptidase

- serine endopeptidase

- aspartatic endopeptidases received February 18, 2008

revised March 14, 2008

accepted March 18, 2008

\section{Bibliography}

DOI $10.1055 / \mathrm{s}-2008-1074530$

Planta Med 2008; 74: 699-711

(c) Georg Thieme Verlag KG

Stuttgart · New York

Published online May 21, 2008

ISSN 0032-0943

Correspondence

\section{Prof. Dr. Matthias F. Melzig}

Institute of Pharmacy

Free University Berlin

Königin-Luise-Str. $2+4$

14195 Berlin

Germany

Tel.: +49-30-838-51451

Fax: +49-30-838-51461

matthias.melzig@fu-berlin.de

\section{Abstract}

$\nabla$

Proteases appear to play key roles in the regulation of biological processes in plants, such as the recognition of pathogens and pests and the induction of effective defence responses. On the other side these enzymes are able to activate protease-activated receptors (PARs) and in that way to act as agents with pharmacological and toxicological significance. An important source of plant proteases used in traditional medicine and industry is latex. Over 110 latices of different plant families are known to contain at least one proteolytic enzyme. Most of them belong to the cysteine or serine endopeptidases family and only one to the aspartatic endopeptidases family. This review focuses on the characterization of proteases found in latices of several plant families (Apocynaceae, Asclepiadaceae, Asteraceae, Caricaceae, Convolvulaceae, Euphorbiaceae, Moraceae), and summarizes the known chemical and biological properties of the isolated proteases as well as their importance in pharmacology and toxicology.

\section{Introduction}

\section{$\nabla$}

Proteolytic enzymes in plants are involved in almost all aspects of growth and development including germination, circadian rhythms, senescence and programmed cell death. Similarities can be seen to proteolytic enzymes in animals playing a major role in digestion, immune system and signal transduction. An important source of plant proteases is latex. The utilization of this plant product in traditional medicine and industry is well known. Until today the research in proteases present in latices was focused mainly in commercial applications [1] or in relation to allergic problems [2]. A systematic overview about the occurrence and properties of this group of en-

\section{Abbreviations \\ $\nabla$ \\ Ac-Phe-Arg-pNA: $N$-acetyl-phenylalanine-argi- nine-p-nitroanilide \\ APMSF: $\quad$-amidinomethanesulfonyl fluoride \\ CGN: carboxybenzoxyglycine p-nitrophenyl ester}

DEAE-sepharose: diethylaminoethyl-sepharose DEPC:

DFP:

E-64: diethyl pyrocarbonate diisopropyl fluorophosphate trans-epoxysuccinyl-L-leucylamido-(4-guanidino)butane

IAA:

PAR:

PCMB:

PFLNA: iodoacetamide protease-activated receptor $p$-chloromercury benzoate L-pyroglutamyl-L-phenylalanyl-s-leucine-p-nitroanilide

PMSF: phenylmethanesulfonyl fluoride

zymes correlated to plant families and assigned to biochemical defined protease types was lacking. A knowledge about the chemical properties of plant proteases might open new insights into the biological effects induced by proteases via PARs from latex-bearing plants, and could be a scientific aid for chemotaxonomic studies therefore this review will summarize the literature about these enzymes.

Latex is an aqueous suspension or emulsion of various kinds of particles borne within living cells. In the complex emulsion/suspension proteins, alkaloids, starches, sugars, oil, tannins, resins, and gums are found. In most plants, latex is white, but some have yellow, orange, or scarlet latex. Laticifers, the latex-bearing structures, 
vary in origin, anatomy, and distribution. Latex is wide spread in plants - 40 families and more than 20,000 species are estimated to bear laticiferous structures of some kind [3]. The presence of proteolytic enzymes in latices from plants of diverse families has been known for many years. The functions of these proteases which come from different genetic resources have not been elucidated. One possible function is the degradation of proteins during laticifer development or promotion of coagulation. Some plants immediately secrete latex when the leaves, stems, and fruits are injured. The latex bleeding proceeds for a few minutes until a clot forms around the wounded area. The coagulation process is vital for plant defence against possible pathogen attack. Latex itself may act to shield the cambial meristem and the contents of the sieve tubes from predators, or to ward off parasites or pathogens. Therefore, it seems reasonable to assume that the substances and enzymes needed for such purposes are present in latex [4].

Latex proteases have been found to protect ripening fruits against plant pathogens such as insects and fungi [5]. The presence of bacteriolytic activity in latices of Carica papaya L., Ficus glabrata H.B.K., and Ervatamia coronaria (Jaqu.) Stapf [syn. Tabernaemontana divaricata (L.) R.Br. ex Roem. et Schult.] confirms the fact that they act in unison. Proteolytic enzymes play a key role in plant physiology. They not only maintain the protein pool of the cell but also are involved in various intra- and extracellular processes like leaf senescence, breakdown of storage proteins in germinating seeds, development and ripening of fruits, regulatory mechanisms, and others. The tissues which are metabolically very active have abundant endopeptidases activity [6].

Protease, peptidase, proteinase or proteolytic enzymes are names for the enzymes that hydrolyze peptide bonds. Most peptidases are either exopeptidases cleaving one or a few amino acids from the $\mathrm{N}$ - or $\mathrm{C}$-terminus, or endopeptidases that act internally in polypeptide chains [3]. The enzyme subclass of endopeptidases (EC 3.4) is, in turn, divided into sub-subclasses: enzymes belonging to subclass EC3.4.21 (serine proteases) possess a Ser residue in the active site; those belonging to EC 3.4.22 (cysteine proteases) have a Cys residue instead; those belonging to EC 3.4.23 (aspartatic proteases) depend on an Asp residue for their catalytic activity; and those belonging to EC 3.4.24 (metalloproteases) use a metal ion (normally $\mathrm{Zn}^{2+}$ ) in their catalytic mechanism [7]. Most proteases found in latices belong to the cysteine and serine protease family, only one is a member of the aspartatic proteases family and none is yet known to be a metalloprotease. This review surveys the literature of the last 60 years (Medline, SciFinder Scholar and Interscience as databases). The known latex proteases are classified by their belonging to one of the endopeptidases families. If there are known pharmacological or toxicological aspects of a protease they will be mentioned below. Chemical properties are listed in Table 1, - Table 2, and $\bullet$ Table 3.

We use the Asclepiadaceae as an own family. There are hints that they are now included in the Apocynaceae as a subfamily.

\section{Serine Proteases EC 3.4.21 \\ $\nabla$}

There are about 40 families of serine-type peptidases which are grouped into 6 clans. The catalytic machinery usually involves in addition to the serine that carries the nucleophile a proton donor. In clans SA, SB, SC and SH, the proton donor is a histidine residue, and there is a catalytic triad because a third residue is required, probably for orientation of the imidazolium ring of the histidine. This is usually an aspartate, but is another histidine in clan SH. In clans SE and SF, a lysine residue has the role of proton donor, and a third catalytic residue is not required. In clan SF, there are some peptidases that have a Ser/His catalytic dyad. Clans SA, SB and SC share a catalytic triad of serine (S), aspartate (D) and histidine (H) in different orders (e.g., HDS in clan SA, DHS in clan SB and SDH in clan SC) [8].

The basic mechanism of action of serine proteases involves transfer of the acyl portion of a substrate to a functional group of the enzyme (a feature shared with other transferases). The two basic steps of catalysis by this group of enzymes thus include:

- firstly, the formation of an ester bond between the oxygen atom of serine and the acyl portion of the substrate - which produces a tetrahedral intermediate and releases the amino part of the substrate;

- and secondly, the attack of water on the acyl-enzyme intermediate, which breaks it down and releases the acidic product - while regenerating the original enzyme form. This mechanism is shown in detail in Fig. 1.

The roles of serine proteases in microsporogenesis, symbiosis, hypersensitive response, signal transduction and differentiation, senescence, and protein degradation/processing have been reviewed by Antao [7].

\section{Isolation and chemical properties}

Purification methods of plant serine proteases often include ammonium sulfate precipitation, column chromatography and gel filtration, but also more specific techniques including affinity chromatography, gel exclusion chromatography, chromatofocusing, and hydrophobic interaction chromatography. The molecular weights of serine proteases vary from 33 to $117 \mathrm{kDa}$, the majority lies between 60 and $80 \mathrm{kDa}$. Most of these enzymes are stable over a wide range of $\mathrm{pH}(2.5-11)$ and temperature (up to $80^{\circ} \mathrm{C}$ ). The optimum temperature for their activity is variable among these enzymes from $40-75^{\circ} \mathrm{C}$ - but most of them act best in the range 60 to $70^{\circ} \mathrm{C}$. The $\mathrm{pH}$ optimum is in the range of pH 5.2 to 10 . The most commonly used compounds concerning the inhibition of latex serine proteases are diisopropyl fluorophosphate (DFP), phenylmethanesulfonyl fluoride (PMSF), $p$ amidinomethanesulfonyl fluoride (APMSF), chymostatin and diethyl pyrocarbonate (DEPC). All these properties are listed in - Table 1.

\section{Properties of different serine proteases from \\ latex-bearing plants}

Macluralisin: Maclura pomifera (Raf.) Schneid is a tree with greenish-yellow latex containing fruits that is commonly grown in the Caucasus area, Southern Ukraine, Central Asia, and in the south of the USA. It is a member of the Moraceae family and commonly known as Osage orange. The enzyme is a glycoprotein with a molecular mass of $65 \mathrm{kDa}$; its protein moiety corresponds to a molecular mass of $50 \mathrm{kDa}$. The substrate specificity of Macluralisin towards synthetic peptides and insulin B-chain is similar to that of Cucumisin, a Subtilisin-like proteinase from the melon fruit. The N-terminal sequence shares $30 \%$ homology with the sequence of Subtilisin-like proteinase K from Tritirachium album [9].

Taraxalisin: The protease was isolated from the latex of Taraxacum officinale Webb s.l. Compositae (Asteraceae) roots. Dandelion belongs to biennial or perennial herbs, which forms 
Table 1 Serine proteases

\begin{tabular}{|c|c|c|c|c|c|c|c|c|c|}
\hline \multirow[t]{2}{*}{ Protease } & \multirow[t]{2}{*}{ Plant } & \multirow{2}{*}{$\begin{array}{l}\text { Molecular } \\
\text { mass } \mathrm{M}_{\mathrm{r}} \\
\text { kDa }\end{array}$} & \multirow{2}{*}{$\begin{array}{l}\text { Isoelectric } \\
\text { point pl }\end{array}$} & \multirow{2}{*}{$\begin{array}{l}\text { Optimum } \\
\text { pH (sub- } \\
\text { strate) }\end{array}$} & \multirow{2}{*}{$\begin{array}{l}\text { Optimum } \\
\text { tempera- } \\
\text { ture }\left[{ }^{\circ} \mathrm{C}\right] \\
\text { (substrate) }\end{array}$} & \multicolumn{2}{|c|}{ Stability range } & \multirow{2}{*}{$\begin{array}{l}\text { Inhibi- } \\
\text { tors }\end{array}$} & \multirow{2}{*}{$\begin{array}{l}\text { Refe- } \\
\text { rence }\end{array}$} \\
\hline & & & & & & $\mathrm{pH}$ & $\begin{array}{l}\text { Tempe- } \\
\text { rature }\end{array}$ & & \\
\hline $\begin{array}{l}\text { Maclurali- } \\
\text { sin }\end{array}$ & $\begin{array}{l}\text { Maclura pomifera } \\
\text { (Raf.) Schneid. } \\
\text { Moraceae }\end{array}$ & 65 & - & $\begin{array}{l}8.5 \\
\text { (Glp-Ala- } \\
\text { Ala-Leu- } \\
\mathrm{NHC} \\
{ }_{6} \mathrm{H}_{4} \mathrm{NO}_{2} \text { ) }\end{array}$ & $\begin{array}{l}58 \text { (Glp-Ala- } \\
\text { Ala-Leu- } \\
\mathrm{NHC}_{6} \mathrm{H}_{4} \mathrm{NO}_{2} \text { ) }\end{array}$ & pH 7-9 & - & DFP & [9] \\
\hline Taraxalisin & $\begin{array}{l}\text { Taraxacum offici- } \\
\text { nale Webb s. I. } \\
\text { Asteraceae }\end{array}$ & 65 & 4.5 & $\begin{array}{l}8.0 \text { (Glp- } \\
\text { Ala-Ala- } \\
\text { Leu-pNa) }\end{array}$ & $\begin{array}{l}40 \text { (Glp-Ala- } \\
\text { Ala-Leu-pNa) }\end{array}$ & $\begin{array}{l}\mathrm{pH} 6.0- \\
9.0\end{array}$ & - & $\begin{array}{l}\text { DFP, } \\
\text { PMSF }\end{array}$ & {$[10]$} \\
\hline $\begin{array}{l}\text { Two } \\
\text { proteases }\end{array}$ & $\begin{array}{l}\text { Synadenium } \\
\text { grantii Hook 'f' } \\
\text { Euphorbiaceae }\end{array}$ & $76 \pm 2$ & - & 7.0 & $\begin{array}{l}60 \text { (azoca- } \\
\text { sein) }\end{array}$ & $\mathrm{pH} 5-10$ & - & $\begin{array}{l}\text { PMSF, } \\
\text { DEPC }\end{array}$ & [11] \\
\hline Protease & $\begin{array}{l}\text { Euphorbia supina } \\
\text { Raf. Euphorbia- } \\
\text { ceae }\end{array}$ & 80 & - & 8.0 (casein) & - & - & - & DFP & [12] \\
\hline $\begin{array}{l}\text { Euphor- } \\
\text { bain L }\end{array}$ & $\begin{array}{l}\text { Euphorbia lathy- } \\
\text { ris L. Euphorbia- } \\
\text { ceae }\end{array}$ & 43 & 4.9 & $7-7.5$ & - & - & - & DFP & [14] \\
\hline $\begin{array}{l}\text { Euphor- } \\
\text { bains } Y_{1} \text {, } \\
Y_{2}, Y_{3}\end{array}$ & $\begin{array}{l}\text { Euphorbia cypa- } \\
\text { rissias L. Euphor- } \\
\text { biaceae }\end{array}$ & $\begin{array}{l}67 \\
33 \\
67\end{array}$ & $\begin{array}{l}5.2,5.2 \\
6.3\end{array}$ & $\begin{array}{l}5.2,5.5 \\
7.0 \text { (azo- } \\
\text { collagen) }\end{array}$ & - & - & - & DFP & [15] \\
\hline $\begin{array}{l}\text { Euphor- } \\
\text { bain P }\end{array}$ & $\begin{array}{l}\text { Euphorbia pul- } \\
\text { cherrima Willd. } \\
\text { Euphorbiaceae }\end{array}$ & 74 & 4.7 & $\begin{array}{l}7.0 \text { (azoca- } \\
\text { sein) }\end{array}$ & - & - & - & $\begin{array}{l}\text { PMSF, } \\
\text { DFP }\end{array}$ & [16] \\
\hline $\begin{array}{l}\text { Euphor- } \\
\text { bains } \mathrm{La}_{1} \text {, } \\
\mathrm{La}_{2}, \mathrm{La}_{3}\end{array}$ & $\begin{array}{l}\text { Euphorbia lactea } \\
\text { Haw. Euphorbia- } \\
\text { ceae }\end{array}$ & $\begin{array}{l}66, \\
44, \\
33\end{array}$ & $\begin{array}{l}7.0 \\
5.0-6.4, \\
4.5\end{array}$ & $\begin{array}{l}\mathrm{La}_{1:} 7.5 \\
\text { (azocolla- } \\
\text { gen) }\end{array}$ & - & - & - & $\begin{array}{l}\text { DFP, } \\
\text { PMSF, } \\
\text { DEPC }\end{array}$ & [17] \\
\hline $\begin{array}{l}\text { Euphor- } \\
\text { bain Lc }\end{array}$ & $\begin{array}{l}\text { Euphorbia lactea } \\
\text { cristata Euphor- } \\
\text { biaceae }\end{array}$ & 70 & $\begin{array}{l}5.0-8.0 \\
(5)\end{array}$ & $\begin{array}{l}8.3 \text { (azo- } \\
\text { collagen) }\end{array}$ & - & - & - & $\begin{array}{l}\text { DFP, } \\
\text { PMSF, } \\
\text { DEPC }\end{array}$ & [17] \\
\hline $\begin{array}{l}\text { Euphor- } \\
\text { bains } T_{1} \text {, } \\
T_{2}, T_{3}, T_{4}\end{array}$ & $\begin{array}{l}\text { Euphorbia tiru- } \\
\text { calli L. Euphor- } \\
\text { biaceae }\end{array}$ & $\begin{array}{l}74, \\
74, \\
74, \\
74\end{array}$ & $\begin{array}{l}5.0-5.5 \\
(4), \\
4.7-5.2 \\
(4), \\
4.0-5.0 \\
(4)\end{array}$ & - & - & - & - & $\begin{array}{l}\text { DFP, } \\
\text { PMSF, } \\
\text { DEPC }\end{array}$ & [18] \\
\hline Protease & $\begin{array}{l}\text { Euphorbia pseu- } \\
\text { do-chamaesyce } \\
\text { Fisch. Euphor- } \\
\text { biaceae }\end{array}$ & 82 & - & 7.5 (casein) & - & - & - & DFP & [19] \\
\hline Milin & $\begin{array}{l}\text { Euphorbia milii } \\
\text { Des Moul. Eu- } \\
\text { phorbiaceae }\end{array}$ & 51.4 & 7.2 & 8.0 (casein) & 60 & $\begin{array}{l}\text { pH } \\
5.5-12\end{array}$ & $\begin{array}{l}\text { up to } \\
65^{\circ} \mathrm{C}\end{array}$ & $\begin{array}{l}\text { PMSF, } \\
\text { APMSF, } \\
\text { DFP }\end{array}$ & [20] \\
\hline $\begin{array}{l}\text { Hevains A, } \\
B, L\end{array}$ & $\begin{array}{l}\text { Hevea brasiliensis } \\
\text { Muell. Arg Eu- } \\
\text { phorbiaceae }\end{array}$ & $\begin{array}{l}69 \\
58 \\
80\end{array}$ & $\begin{array}{l}4.3 \\
4.8-5.3 \\
(4), \\
4.9-6.9 \\
(6)\end{array}$ & $\begin{array}{l}\text { A: } 6.6, \mathrm{~B}: \\
6.3, \mathrm{~L}: 6.3 \\
\text { and } 7.7 \\
(\mathrm{CGN})\end{array}$ & - & - & - & $\begin{array}{l}\text { PMSF, } \\
\text { DFP, } \\
\text { DEPC }\end{array}$ & $\begin{array}{l}{[21],} \\
{[22]}\end{array}$ \\
\hline $\begin{array}{l}\text { Euphor- } \\
\text { bains } \mathrm{D}_{1} \text {, } \\
\mathrm{D}_{2}\end{array}$ & $\begin{array}{l}\text { Elaeophorbia } \\
\text { drupifera } \\
\text { (Schum.) Stapf. } \\
\text { Euphorbiaceae }\end{array}$ & $\begin{array}{l}117, \\
65\end{array}$ & $\begin{array}{l}5.8-7.5 \\
(5), \\
5.2-9.1 \\
(5)\end{array}$ & $\begin{array}{l}6.3 \text { and } 7.8 \\
\left(D_{1}\right), 6.5 \\
\text { and } 7.8 \\
\left(D_{2}\right) \text { (azo- } \\
\text { collagen) }\end{array}$ & - & - & - & $\begin{array}{l}\text { PMSF, } \\
\text { DEPC }\end{array}$ & [23] \\
\hline $\begin{array}{l}\text { Parthe- } \\
\text { nain }\end{array}$ & $\begin{array}{l}\text { Parthenium ar- } \\
\text { gentatum A. Gray } \\
\text { Asteraceae }\end{array}$ & 63 & 6.3 & $\begin{array}{l}7.0-8.0 \\
\text { (Z-glycine- } \\
\text { p-nitro- } \\
\text { phenyl- } \\
\text { ester) }\end{array}$ & - & - & - & $\begin{array}{l}\text { PMSF, } \\
\text { DEPC, } \\
\text { Chymos- } \\
\text { tatin }\end{array}$ & [24] \\
\hline $\begin{array}{l}\text { Artocar- } \\
\text { pin }\end{array}$ & $\begin{array}{l}\text { Artocarpus } \\
\text { heterophyllus } \\
\text { Lam. Moraceae }\end{array}$ & 79.5 & 6.3 & 8.0 (casein) & 60 (casein) & - & - & PMSF & [25] \\
\hline
\end{tabular}




\begin{tabular}{|c|c|c|c|c|c|c|c|c|c|}
\hline \multirow[t]{2}{*}{ Protease } & \multirow[t]{2}{*}{ Plant } & \multirow{2}{*}{$\begin{array}{l}\text { Molecular } \\
\text { mass } \mathrm{M}_{\mathrm{r}} \\
\text { kDa }\end{array}$} & \multirow{2}{*}{$\begin{array}{l}\text { Isoelectric } \\
\text { point pl }\end{array}$} & \multirow{2}{*}{$\begin{array}{l}\text { Optimum } \\
\text { pH (sub- } \\
\text { strate) }\end{array}$} & \multirow{2}{*}{$\begin{array}{l}\text { Optimum } \\
\text { tempera- } \\
\text { ture }\left[{ }^{\circ} \mathrm{C}\right] \\
\text { (substrate) }\end{array}$} & \multicolumn{2}{|c|}{ Stability range } & \multirow{2}{*}{$\begin{array}{l}\text { Inhibi- } \\
\text { tors }\end{array}$} & \multirow{2}{*}{$\begin{array}{l}\text { Refe- } \\
\text { rence }\end{array}$} \\
\hline & & & & & & $\mathrm{pH}$ & $\begin{array}{l}\text { Tempe- } \\
\text { rature }\end{array}$ & & \\
\hline Carnein & $\begin{array}{l}\text { Ipomoea carnea } \\
\text { ssp. fistulosa } \\
\text { (Mart. Ex Choisy) } \\
\text { D.F. Austin Con- } \\
\text { volvulaceae }\end{array}$ & 80.236 & 6.5 & 6.5 & 60 & $\begin{array}{l}\mathrm{pH} \\
3.0-10.0\end{array}$ & $35-70^{\circ} \mathrm{C}$ & $\begin{array}{l}\text { PMSF, } \\
\text { DFP, } \\
\text { Chymos- } \\
\text { tatin }\end{array}$ & [26] \\
\hline Ficin $\mathrm{E}$ & $\begin{array}{l}\text { Ficus elastica } \\
\text { Roxb. Moraceae }\end{array}$ & 50 & 3.7 & $\begin{array}{l}6.0 \\
\text { (azocolla- } \\
\text { gen) }\end{array}$ & - & - & - & DFP & [27] \\
\hline $\begin{array}{l}\text { Cryptole- } \\
\text { pain }\end{array}$ & $\begin{array}{l}\text { Cryptolepis } \\
\text { buchananii } \\
\text { Roem.\& Schult. } \\
\text { Asclepiadaceae }\end{array}$ & 79.5 & 6.3 & $\begin{array}{l}8-10 \\
\text { (azoalbu- } \\
\text { min) }\end{array}$ & $\begin{array}{l}65-75 \\
\text { (azoalbu- } \\
\min )\end{array}$ & $\begin{array}{l}\mathrm{pH} \\
2.5-11.5\end{array}$ & $\begin{array}{l}\text { up to } \\
80^{\circ} \mathrm{C}\end{array}$ & $\begin{array}{l}\text { DFP, } \\
\text { PMSF }\end{array}$ & {$[16]$} \\
\hline
\end{tabular}

Table 2 Aspartatic protease

\begin{tabular}{|c|c|c|c|c|c|c|c|}
\hline Protease & Plant & $\begin{array}{l}\text { Molecular } \\
\text { weight } \mathrm{M}_{\mathrm{r}} \\
\text { kDa }\end{array}$ & pH optima & $\begin{array}{l}\text { Temperature opti- } \\
\text { ma (substrate) }\end{array}$ & $\begin{array}{l}\text { Stability range } \\
\mathrm{pH} / \text { temperature }\end{array}$ & Inhibitor & Ref. \\
\hline Protease & $\begin{array}{l}\text { Ficus racemosa } \\
\text { L. Moraceae }\end{array}$ & $44.5 \pm 05$ & $4.5-6.5$ & $60 \pm 0.5$ (azocasein) & $\begin{array}{l}\mathrm{pH} 4.0-7.5 / \\
\text { up to } 70^{\circ} \mathrm{C}\end{array}$ & Pepstatin A & [28] \\
\hline
\end{tabular}

rosettes of leaves during the first year and form flower buds when still under the snow. The proteolytic activity depends on the phase of seasonal development; maximal activity of the proteinase in the roots is attained in April at the beginning of plant development after the winter period. The molecular mass of taraxalisin is $67 \mathrm{kDa}$. Taraxalisin is similar to Cucumisin and Macluralisin in terms of substrate specificity towards synthetic substrates and insulin B-chain. The N-terminal sequence has $40 \%$ of its residues identical to those of Subtilisin Carlsberg [10].

Proteases from the latex of Synadenium grantii Hook. ' $f$ : Two proteolytically active fractions "A" and "B" were isolated from the latex of Synadenium grantii Hook. ' $\mathrm{f}$ ', commonly known as African milkbush (Euphorbiaceae). Both were completely inhibited by PMSF indicating that they are serine proteases, histidine residues also appear to play an important role in catalysis, as demonstrated by inhibition with DEPC [10].

Protease B from the latex of Euphorbia supina Rafin. (Euphorbiaceae): The N-terminal sequence of the first fifteen residues was determined and six of the residues match those of Cucumisin [EC 3.4.21.25], indicating that the E. supina protease is a Cucumisinlike serine protease. The specificity of the protease is broad, but the preferential cleavage sites were of hydrophobic amino acid residues. The latex of E. supina had strong caseinolytic activity, in contrast to the homogenate from the stems and leaves. Approximately $1.6 \mathrm{mg}$ of the purified enzyme were obtained from $3 \mathrm{~kg}$ of E. supina stems and leaves. The elution profile from the DEAE-Sepharose column chromatography showed a main activity peak, E. supina protease B and a minor activity peak, termed E. supina protease A (not characterized) [12].

Euphorbain L: Euphorbain L is a proteinase from the latex of Euphorbia lathyris L. (Euphorbiaceae), commonly known as caper spurge, a biennial plant which grows to a height of about
$1 \mathrm{~m}$. The enzyme is inhibited by diisopropyl fluorophosphates, indicating that there is a serine at the active site. Euphorbain $\mathrm{L}$ displays a preference for both the $\mathrm{C}$ - and $\mathrm{N}$-bonds of leucine residues which is notably greater than for other sites of attack. The amino acid composition of Euphorbain $L$ was expressed as percent residue weight; there is a notable similarity between Euphorbain L and Cocoonase (Cocoonase has also been identified as a serine protease) [13], [14].

Euphorbains Y-1, Y-2, Y-3: Three serine-centered proteolytic enzymes were isolated from the latex of Euphorbia cyparissias L. (cypress spurge, Euphorbiaceae). The proteases which are glycoproteins are immunologically distinct from Euphorbain L, but related to that enzyme in amino acid composition. The three Euphorbains have different activities to both esterolytic and proteolytic substrates and react in individual ways in digesting of insulin B-chain [15].

Euphorbain P: Euphorbain P was purified from the latex of Euphorbia pulcherrima Willd., Poinsettia, Christmas star (Euphorbiaceae). The enzyme is effectively inhibited by the classic serine protease inhibitors DFP and PMSF. This multi-chain enzyme is similar in composition to one in Euphorbia lathyris L., but is larger in size and has more restricted activity. Euphorbain $\mathrm{P}$ is also a glycoprotein containing glucosamine [16].

Euphorbains La1, La2, La3 and Lc: The latices of two succulent Euphorbiaceae, Euphorbia lactea Haw., Candelabra plant, and Euphorbia lactea Haw. "cristata" (brain cactus), a crested 'monstrosa' variety which bears little physical resemblance to $E$. lactea, were examined. The Euphorbains from E. lactea (La1, La2, La3) and E. lactea cristata (Lc) are related to each other in amino acid composition even though they display different physical and biochemical properties. The proteases from both are distinct from those isolated from other members of the genus Euphorbia. 
Table 3 Cysteine proteases

\begin{tabular}{|c|c|c|c|c|c|c|c|c|c|}
\hline \multirow[t]{2}{*}{ Protease } & \multirow[t]{2}{*}{ Plant } & \multirow{2}{*}{$\begin{array}{l}M_{r} \\
k D a\end{array}$} & \multirow[t]{2}{*}{ pl } & \multirow{2}{*}{$\begin{array}{l}\text { pH opti- } \\
\text { mum } \\
\text { (sub- } \\
\text { strate) }\end{array}$} & \multirow{2}{*}{$\begin{array}{l}\text { Tempera- } \\
\text { ture opti- } \\
\text { mum }\left[{ }^{\circ} \mathrm{C}\right] \\
\text { (substrate) }\end{array}$} & \multicolumn{2}{|c|}{ Stability range } & \multirow{2}{*}{$\begin{array}{l}\text { Inhibi- } \\
\text { tors }\end{array}$} & \multirow[t]{2}{*}{ Ref. } \\
\hline & & & & & & $\mathrm{pH}$ & $\begin{array}{l}\text { Temper- } \\
\text { ature }\end{array}$ & & \\
\hline $\begin{array}{l}\text { Ervatamin } \\
\text { A }\end{array}$ & $\begin{array}{l}\text { Ervatamia coro- } \\
\text { naria (Jacq.) } \\
\text { Stapf. Apocyna- } \\
\text { ceae }\end{array}$ & 27.6 & 8.37 & $\begin{array}{l}8.0-8.5 \\
\text { (azoal } \\
\text { bumin) }\end{array}$ & $\begin{array}{l}50-55 \\
\text { (azoal } \\
\text { bumin) }\end{array}$ & $\begin{array}{l}\mathrm{pH} \\
3.0-12\end{array}$ & $40-80^{\circ} \mathrm{C}$ & $\begin{array}{l}\text { IAA, } \\
\text { sodium } \\
\text { tetrathio- } \\
\text { nate, } \\
\text { mercuric } \\
\text { chloride }\end{array}$ & [42] \\
\hline $\begin{array}{l}\text { Ervatamin } \\
\text { B }\end{array}$ & $\begin{array}{l}\text { Ervatamia coro- } \\
\text { naria (Jacq.) } \\
\text { Stapf. Apocyna- } \\
\text { ceae }\end{array}$ & 26 & 9.35 & $\begin{array}{l}6.0-6.5 \\
\text { (azoca- } \\
\text { sein), } 7.0- \\
7.5 \text { (azoal- } \\
\text { bumin) }\end{array}$ & $50-55$ & $\begin{array}{l}\text { pH } \\
3.0-10.5\end{array}$ & $\begin{array}{l}\text { up to } \\
62{ }^{\circ} \mathrm{C}\end{array}$ & $\begin{array}{l}\text { PCMB, } \\
\text { mercuric } \\
\text { chloride, } \\
\text { IAA }\end{array}$ & [43] \\
\hline $\begin{array}{l}\text { Ervatamin } \\
\text { C }\end{array}$ & $\begin{array}{l}\text { Ervatamia coro- } \\
\text { naria (Jacq.) } \\
\text { Stapf. Apocyna- } \\
\text { ceae }\end{array}$ & 23 & 9.54 & $\begin{array}{l}7.5-8.0 \\
\text { (azoalbu- } \\
\text { min) }\end{array}$ & $\begin{array}{l}50 \text { (azoalbu- } \\
\min \text { ) }\end{array}$ & $\mathrm{pH} 2-12$ & $\begin{array}{l}\text { up to } \\
70^{\circ} \mathrm{C}\end{array}$ & $\begin{array}{l}\text { IAA, } \\
\text { mercuric } \\
\text { chloride }\end{array}$ & $\begin{array}{l}{[5],} \\
{[44],} \\
{[45],} \\
{[84]}\end{array}$ \\
\hline Heynein & $\begin{array}{l}\text { Ervatamia hey- } \\
\text { neana (Wall.) } \\
\text { T.Cooke Apocy- } \\
\text { naceae }\end{array}$ & 23 & 10.8 & $\begin{array}{l}8.0-8.5 \\
\text { (hemoglo- } \\
\text { bin) }\end{array}$ & $52 \pm 2$ & $\begin{array}{l}\mathrm{pH} \\
2.5-11.5\end{array}$ & $\begin{array}{l}\text { up to } \\
63^{\circ} \mathrm{C}\end{array}$ & $\begin{array}{l}\text { E-64, } \\
\text { IAA, } \\
\text { mercuric } \\
\text { chloride, } \\
\text { PCMB, } \\
\text { sodium } \\
\text { tetra- } \\
\text { thionate }\end{array}$ & [5] \\
\hline $\begin{array}{l}\text { Funastrain } \\
\mathrm{CII}\end{array}$ & $\begin{array}{l}\text { Funastrum clau- } \\
\text { sum (Jacq.) } \\
\text { Schlechter } \\
\text { Apocynaceae }\end{array}$ & 23.636 & $>9.3$ & $\begin{array}{l}9-10 \\
\text { (casein), } \\
6.2-6.8 \\
\text { (PFLNA) }\end{array}$ & - & pH 6-11 & $\begin{array}{l}\text { up to } \\
70^{\circ} \mathrm{C}\end{array}$ & E-64 & [47] \\
\hline $\begin{array}{l}\text { Morrenain } \\
\mathrm{BI}\end{array}$ & $\begin{array}{l}\text { Morrenia bra- } \\
\text { chystephana Gri- } \\
\text { seb. Asclepiada- } \\
\text { ceae }\end{array}$ & 23.205 & $>9.3$ & $\begin{array}{l}8.4-9.0 \\
\text { (casein) }\end{array}$ & - & $\begin{array}{l}\mathrm{pH} \\
6.8-10.4\end{array}$ & $\begin{array}{l}\text { up to } \\
70^{\circ} \mathrm{C}\end{array}$ & $\begin{array}{l}\text { E-64, } \\
\text { iodoace- } \\
\text { tate }\end{array}$ & $\begin{array}{l}{[48],} \\
{[49],} \\
{[50]}\end{array}$ \\
\hline $\begin{array}{l}\text { Morrenain } \\
\text { BII }\end{array}$ & $\begin{array}{l}\text { Morrenia bra- } \\
\text { chystephana Gri- } \\
\text { seb. Asclepiada- } \\
\text { ceae }\end{array}$ & 25.5 & $>9.3$ & $\begin{array}{l}7.5-9.0 \\
\text { (casein) }\end{array}$ & - & - & - & E-64 & $\begin{array}{l}\text { [48], } \\
{[49],} \\
{[50]}\end{array}$ \\
\hline $\begin{array}{l}\text { Morrenain } \\
\text { OII }\end{array}$ & $\begin{array}{l}\text { Morrenia odorata } \\
\text { (Hook et Arn.) } \\
\text { Asclepiadaceae }\end{array}$ & 25.8 & $>9.3$ & $\begin{array}{l}7.0-10.0 \\
\text { (casein) }\end{array}$ & - & $\begin{array}{l}\mathrm{pH} \\
6.0-11.0\end{array}$ & - & - & [48] \\
\hline $\begin{array}{l}\text { Asclepain } \\
\mathrm{F}\end{array}$ & $\begin{array}{l}\text { Asclepias frutico- } \\
\text { sa L. Asclepiada- } \\
\text { ceae }\end{array}$ & 23.652 & $>9.3$ & $\begin{array}{l}8.5-10.5 \\
\text { (casein) }\end{array}$ & - & $\begin{array}{l}\mathrm{pH} \\
6.0-12.0\end{array}$ & - & $\begin{array}{l}\text { E-64, } \\
\text { mercuric } \\
\text { chloride, } \\
\text { IAA }\end{array}$ & [51] \\
\hline $\begin{array}{l}\text { Asclepain } \\
\mathrm{Cl}\end{array}$ & $\begin{array}{l}\text { Asclepias cura- } \\
\text { ssavica L. Ascle- } \\
\text { piadaceae }\end{array}$ & 23.2 & $>9.3$ & 8.5 & - & $\begin{array}{l}\mathrm{pH} \\
6.0-10.0\end{array}$ & $\begin{array}{l}\text { up to } \\
60^{\circ} \mathrm{C}\end{array}$ & E-64 & [52] \\
\hline $\begin{array}{l}\text { Asclepains } \\
\text { A3, B5 }\end{array}$ & $\begin{array}{l}\text { Asclepias syrica L. } \\
\text { Asclepiadaceae }\end{array}$ & 23,21 & - & $\begin{array}{l}7.5-8.5 \\
\text { (A3) } \\
\text { (casein), } \\
7.0-7.5 \\
\text { (B5) } \\
\text { (casein) }\end{array}$ & - & - & - & $\begin{array}{l}\text { IAA, } \\
\text { sodium } \\
\text { tetra- } \\
\text { thionate }\end{array}$ & [53] \\
\hline $\begin{array}{l}\text { Asclepain } \\
\text { G } \\
\text { (10 forms) }\end{array}$ & $\begin{array}{l}\text { Asclepias glau- } \\
\text { cescens H.B.K. } \\
\text { Asclepiadaceae }\end{array}$ & $\begin{array}{l}\mathrm{Ag}_{3} 22.6, \\
\mathrm{Ag}_{6} 23.5, \\
\mathrm{Ag}_{7} 23, \\
\mathrm{Ag}_{8} 23.5\end{array}$ & $>9$ & - & - & - & - & - & [54] \\
\hline $\begin{array}{l}\text { Asclepain } \\
\text { S }\end{array}$ & $\begin{array}{l}\text { Asclepias specio- } \\
\text { sa Torr. Asclepia- } \\
\text { daceae }\end{array}$ & - & - & $7.0-8.0$ & $65-75$ & - & $\begin{array}{l}\text { up to } \\
85^{\circ} \mathrm{C}\end{array}$ & $\begin{array}{l}\text { iodoace- } \\
\text { tate }\end{array}$ & [55] \\
\hline
\end{tabular}




\begin{tabular}{|c|c|c|c|c|c|c|c|c|c|}
\hline \multirow[t]{2}{*}{ Protease } & \multirow[t]{2}{*}{ Plant } & \multirow{2}{*}{$\begin{array}{l}M_{r} \\
k D a\end{array}$} & \multirow[t]{2}{*}{ pl } & \multirow{2}{*}{$\begin{array}{l}\text { pH opti- } \\
\text { mum } \\
\text { (sub- } \\
\text { strate) }\end{array}$} & \multirow{2}{*}{$\begin{array}{l}\text { Tempera- } \\
\text { ture opti- } \\
\text { mum }\left[{ }^{\circ} \mathrm{C}\right] \\
\text { (substrate) }\end{array}$} & \multicolumn{2}{|c|}{ Stability range } & \multirow{2}{*}{$\begin{array}{l}\text { Inhibi- } \\
\text { tors }\end{array}$} & \multirow[t]{2}{*}{ Ref. } \\
\hline & & & & & & $\mathrm{pH}$ & $\begin{array}{l}\text { Temper- } \\
\text { ature }\end{array}$ & & \\
\hline $\begin{array}{l}\text { Calotro- } \\
\text { pins DI, DII }\end{array}$ & $\begin{array}{l}\text { Calotropis gigan- } \\
\text { tea (L.) Dyrand. } \\
\text { Asclepiadaceae }\end{array}$ & $\begin{array}{l}23.8 \\
24.2\end{array}$ & $\begin{array}{l}9.55 \\
9.65\end{array}$ & $7.5-8.0$ & 55 & - & - & IAA & $\begin{array}{l}{[58],} \\
{[60]}\end{array}$ \\
\hline Procerain & $\begin{array}{l}\text { Calotropis pro- } \\
\text { cera (Aiton) Dry- } \\
\text { and. Asclepiada- } \\
\text { ceae }\end{array}$ & 28.8 & 9.32 & $\begin{array}{l}7.0-9.0 \\
\text { (azoalbu- } \\
\min )\end{array}$ & $\begin{array}{l}55-60^{\circ} \mathrm{C} \\
\text { (azoalbu- } \\
\min \text { ) }\end{array}$ & $\begin{array}{l}\mathrm{pH} \\
3.0-12.0\end{array}$ & $\begin{array}{l}\text { up to } \\
70^{\circ} \mathrm{C}\end{array}$ & $\begin{array}{l}\text { E-64, } \\
\text { PCMB, } \\
\text { mercuric } \\
\text { chloride, } \\
\text { IAA }\end{array}$ & {$[32]$} \\
\hline $\begin{array}{l}\text { Araujiain } \\
\mathrm{HI}\end{array}$ & $\begin{array}{l}\text { Araujia hortorum } \\
\text { Fourn. Asclepia- } \\
\text { daceae }\end{array}$ & 24.03 & $>9.3$ & $\begin{array}{l}8.0-9.5 \\
\text { (casein) }\end{array}$ & 60 & - & - & $\begin{array}{l}\text { E-64, } \\
\text { mercuric } \\
\text { chloride }\end{array}$ & {$[62]$} \\
\hline $\begin{array}{l}\text { Araujiain } \\
\mathrm{HII}\end{array}$ & $\begin{array}{l}\text { Araujia hortorum } \\
\text { Fourn. Asclepia- } \\
\text { daceae }\end{array}$ & 23.718 & 8.9 & $\begin{array}{l}8.0-9.0 \\
\text { (casein) }\end{array}$ & - & $\begin{array}{l}\mathrm{pH} \\
6.5-11.5\end{array}$ & $\begin{array}{l}\text { up to } \\
70^{\circ} \mathrm{C}\end{array}$ & E-64 & {$[63]$} \\
\hline $\begin{array}{l}\text { Araujiain } \\
\text { H III }\end{array}$ & $\begin{array}{l}\text { Araujia hortorum } \\
\text { Fourn. Asclepia- } \\
\text { daceae }\end{array}$ & 23.546 & $>9.3$ & $\begin{array}{l}8.0-9.0 \\
\text { (casein) }\end{array}$ & - & $\begin{array}{l}\mathrm{pH} 7-10 \\
\text { up to } \\
70^{\circ} \mathrm{C}\end{array}$ & - & E-64 & [63] \\
\hline $\begin{array}{l}\text { Philiber- } \\
\text { tain GI }\end{array}$ & $\begin{array}{l}\text { Philiberta gilliesii } \\
\text { Hook. et Arn. } \\
\text { (fruits) Apocyna- } \\
\text { ceae }\end{array}$ & 23.530 & $>10.25$ & $\begin{array}{l}7.6 \text { (ca- } \\
\text { sein), } 6.2- \\
7.2 \\
\text { (PFLNA) }\end{array}$ & - & $\begin{array}{l}\mathrm{pH} \\
5.0-10.0\end{array}$ & - & E-64 & {$[64]$} \\
\hline Mexicain & $\begin{array}{l}\text { Jacartia mexica- } \\
\text { na A. DC. (fruits) } \\
\text { Caricaceae }\end{array}$ & 23.8 & - & $\begin{array}{l}8.5-9.0 \\
\text { (casein) }\end{array}$ & 65 & $\mathrm{pH} 3-10$ & - & E-64 & {$[39,65]$} \\
\hline Papain & $\begin{array}{l}\text { Carica papaya L. } \\
\text { Caricaceae }\end{array}$ & 23.429 & 8.75 & $5.5-7.0$ & - & $\begin{array}{l}\mathrm{pH} \\
4.0-10.0 \\
\text { up to } \\
80^{\circ} \mathrm{C}\end{array}$ & - & E-64 & [8] \\
\hline Caricain & $\begin{array}{l}\text { Carica papaya L. } \\
\text { Caricaceae }\end{array}$ & 23.280 & 11.7 & 7.0 & - & $\mathrm{pH} 3-10$ & - & E-64 & [8] \\
\hline $\begin{array}{l}\text { Chymopa- } \\
\text { pain }\end{array}$ & $\begin{array}{l}\text { Carica papaya L. } \\
\text { Caricaceae }\end{array}$ & 23.650 & $10.3-10.7$ & around 7 & - & $\mathrm{pH} 3-10$ & - & E-64 & [8] \\
\hline $\begin{array}{l}\text { Glycyl-en- } \\
\text { dopepti- } \\
\text { dases }\end{array}$ & $\begin{array}{l}\text { Carica papaya L. } \\
\text { Caricaceae }\end{array}$ & 23.313 & above 10 & around 7 & - & $\mathrm{pH} 3-10$ & - & E-64 & [8] \\
\hline $\begin{array}{l}\text { Endopep- } \\
\text { tidases } \\
\text { CCI, CCII, } \\
\text { CCIII,CCIV, } \\
\text { CC28 }\end{array}$ & $\begin{array}{l}\text { Carica candamar- } \\
\text { censis Hook. f. } \\
\text { Caricaceae }\end{array}$ & $23-28.6$ & $10.5-11.5$ & $6.8(7.0)$ & 60 & - & - & $\begin{array}{l}\text { IAA, E- } \\
64\end{array}$ & [85] \\
\hline $\begin{array}{l}\text { Ficain (EC } \\
3.4 .22 .3 \text { ) }\end{array}$ & $\begin{array}{l}\text { Ficus glabrata } \\
\text { H.B.K. Moraceae }\end{array}$ & - & - & 7.0 & - & $\begin{array}{l}\mathrm{pH} \\
4.0-8.5\end{array}$ & - & - & [8] \\
\hline Ficain PI & $\begin{array}{l}\text { Ficus pumila L. } \\
\text { Moraceae }\end{array}$ & 28.6 & $>9.3$ & $\begin{array}{l}7.0-9.0 \\
\text { (casein) }\end{array}$ & 65 & $\mathrm{pH} 6-11$ & $\begin{array}{l}\text { up to } \\
75^{\circ} \mathrm{C}\end{array}$ & $\begin{array}{l}\text { E-64, } \\
\text { mercuric } \\
\text { chloride }\end{array}$ & [76] \\
\hline $\begin{array}{l}\text { Ficains A, } \\
\text { B, C, D }\end{array}$ & $\begin{array}{l}\text { Ficus carica var. } \\
\text { horaishi Mora- } \\
\text { ceae }\end{array}$ & $24.0-26.0$ & $8.3-10.2$ & 8.0 & 60 & $\begin{array}{l}\mathrm{pH} \\
6.0-11.0\end{array}$ & - & $\begin{array}{l}\text { IAA, } \\
\text { PCMB, } \\
\text { mercuric } \\
\text { chloride, } \\
\text { sodium } \\
\text { tetra- } \\
\text { thionate }\end{array}$ & {$[86]$} \\
\hline Protease & $\begin{array}{l}\text { Ficus hispida L. f. } \\
\text { Moraceae }\end{array}$ & - & $4.4-4.7$ & 7.0 & 40 & - & - & $\begin{array}{l}\text { p-hy- } \\
\text { droxy- } \\
\text { mercuri- } \\
\text { ben- } \\
\text { zoate }\end{array}$ & [77] \\
\hline
\end{tabular}




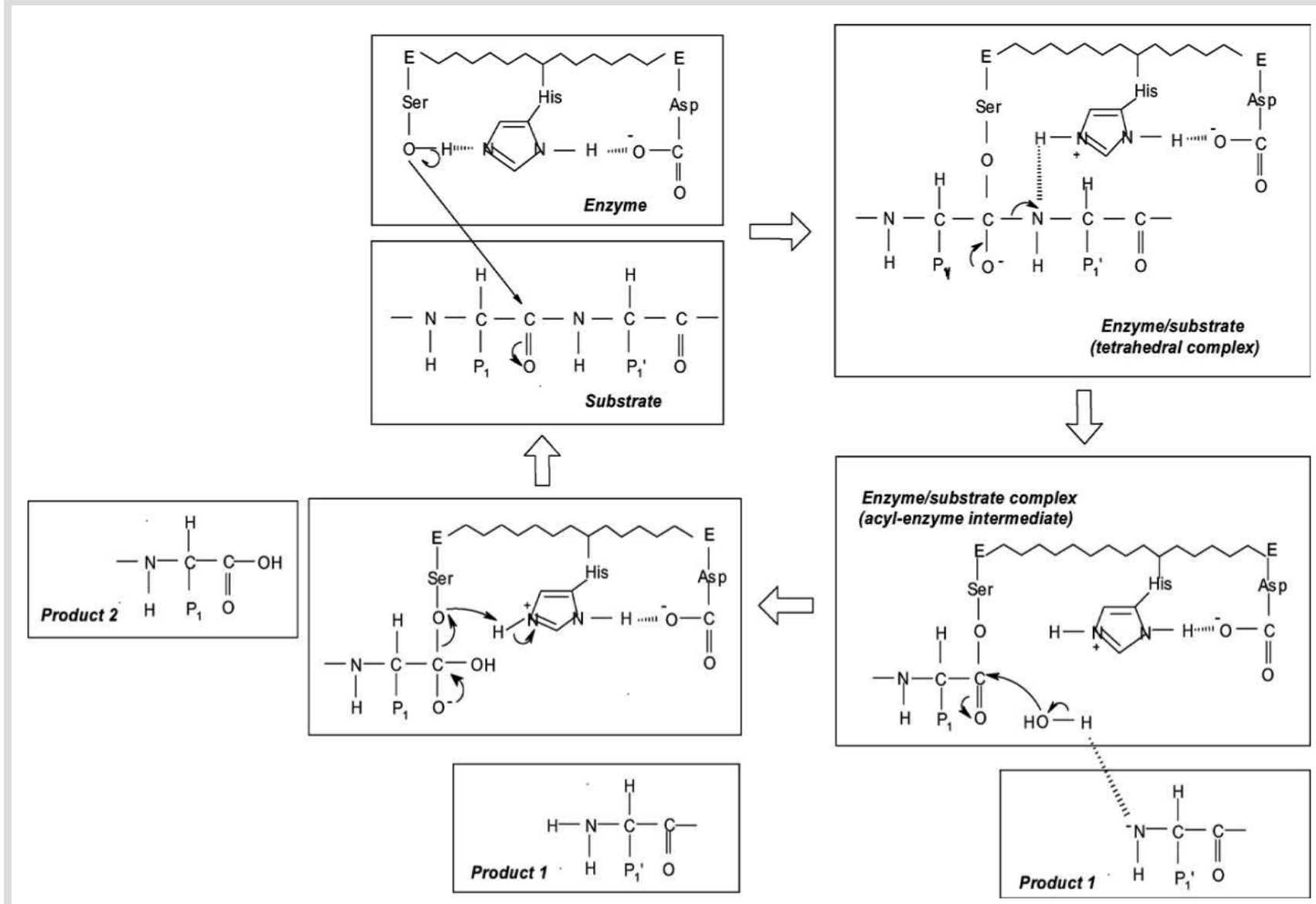

Fig. 1 Mechanism of reactions catalyzed by serine proteases. Adopted from Antao and Malcata [7].

Euphorbains La1 and La3 are singly charged forms with pIs of 7.0 and 4.5 , respectively. The La2 and Lc enzymes are multiply charged forms with 3 and 5, respectively, different isoelectric points [17].

Euphorbains T1, T2, T3, T4: Euphorbains T1-T4 were isolated from the latex of the succulent Euphorbia tirucalli L. (known as milk bush, Euphorbiaceae), which is native to Uganda, Zaire and Tanzania. Each enzyme has several differently charged forms. The four proteases examined are of similar amino acid composition but yield differing two-dimensional maps of tryptic digests. Euphorbain T1 is a glycoprotein containing glucosamine. The enzymes are efficient inhibited by PMSF and DFP and by histidinespecific reagents. There is no close relationship in the amino acid composition of the Euphorbains T1-T4 when comparison is made with the other Euphorbains [18].

Euphorbia protease B from the latex of Euphorbia pseudochamaesyce Fisch. (Euphorbiaceae): Six out of ten amino-terminal residues of Euphorbia protease B were identical to those of Cucumisin. The specificity of Euphorbia protease B was broad and preferred positively charged residues at P1 position and hydrophobic residues at $\mathrm{P} 2$ position. The enzyme reacted with antiCucumisin antibody, showing that Euphorbia protease B from E. pseudochamaesyce belongs to Cucumisin-like proteases [19]. Milin: Milin was purified from the latex of Euphorbia milii Des. Moul. (Euphorbiaceae). This plant is native to Madagascar and cultivated as an ornamental plant in India. The latex of the plant is used to control mollusk proliferation by way of its embryofetotoxicity. It is frequently used in traditional medicine against liver fluke, schistosomiasis in sheep, cattle, and even in humans. Milin is a glycoprotein with a detectable carbohydrate moiety ( $7-8 \%$ ) which is essential for the activity. It is strongly inhibited by serine specific inhibitors. The $\mathrm{N}$-terminal sequence does not match with any sequence of know plant serine proteases [20].

Hevains A, B, L: Hevain A is isolated from the ammonium-treated latex, Hevain $B$ from the serum of freeze-dried latex and hevain $L$ from the lutoid fraction of the freeze-dried latex of Hevea brasiliensis Muell. Arg. (Euphorbiaceae). The amino acid compositions of Hevain A and Hevain B differ significantly but the reactivities to a variety of ester and protein substrates are similar as also are the $\mathrm{pH}$ optima. Hevain $\mathrm{L}$ is a distinct protease with a unique amino acid composition. It displays esterolytic activities and digests the insulin B-chain, but is not proteolytic to azocollagen, azocasein, bovine serum albumin or hemoglobin. The activities of all three enzymes are dependent on the presence of serine and histidine residues [21], [22].

Euphorbains D1, D2: Two proteolytic enzymes were purified from the latex of the West African succulent tree Elaeophorbia drupifera (Schum.) Stapf (Euphorbiaceae). Both enzymes are multiply charged with five isoelectric points, and both display two $\mathrm{pH}$ maxima for proteolytic activity. The molecular masses of Euphorbain D1 and D2 are $117 \mathrm{kDa}$ and $65 \mathrm{kDa}$, respectively, and both are composed of $30 \mathrm{kDa}$ subunits. The subunits are very similar but not identical as seen by tryptic mapping [23].

Parthenain: Parthenain is isolated from the latex of Parthenium argentatum A. Gray (Asteraceae) called Guayule. This latex-car- 
rying shrub is native to semi-arid regions of Mexico and the USA. The enzyme has a preference for neutrally charged amino acid residues in oxidized insulin B-chain. The glycoprotein Parthenain is a member of the serine-centered proteases (inhibition by PMSF) in which histidine plays an essential role (inhibition by diethyl pyrocarbonate and dibromoacetophenone). It shows a partial activation in the presence of a large molar excess of $p$ chloromercuribenzoate [24].

Artocarpin: A serine protease with a relatively broad specificity towards peptide substrates was purified from Jackfruit (Artocarpus heterophyllus Lam., Moraceae) latex. Jackfruit is a wild fruit tree which grows in the forest of tropical Asia and is also cultivated in orchards for its fruits. Artocarpin is activated by thiol-reducing reagents and inhibited by PMSF [25].

Carnein: The enzyme was isolated from the latex of Ipomoea carnea ssp. fistulosa (Martius ex Choisy) D. F. Austin (Morning glory, Convolvulaceae). I. carnea ssp. fistulosa is a toxic plant found in India, Brazil, USA, and other countries. It is an aggressive weed in wetlands toxic to cattle and difficult to eradicate. The extract with water and $80 \%$ ethanol of I. carnea ssp. fistulosa exhibits HIV reverse transcriptase inhibitory activity, therefore, it may be useful in the treatment of AIDS. The N-terminal sequence of Carnein showed a high degree of identity with that of Subtilisin-like serine proteases [26].

Ficin E: Ficin E was purified from the latex of Ficus elastica Roxb., Moraceae. Unlike the proteolytic enzymes of Ficus glabrata H.B.K. and the other members of this genus the protease activity in Ficus elastica is not determined by an active cysteinyl residue. The enzyme is completely and rapidly inhibited by specific serine protease inhibitors such as PMSF and DPF and it is also inhibited by diethyl pyrocabonate specific for histidine residues. The activity of Ficin E depends on intact serine and histidine residues. The amino acid composition of Ficin $\mathrm{E}$ is different to that of the Ficins in Ficus glabrata H.B.K. and Ficus carica L., nor is it closely related in its structure to the proteases from Euphorbiaceae [27].

Cryptolepain: Cryptolepain is a stable glycosylated serine protease purified from the latex of the medicinal important plant Cryptolepis buchananii Roem. et Schult. (Apocynaceae). Various parts of the plant are used as antidiarrhoeal, antibacterial, antiulcerative, anti-inflammatory agents, blood purifiers, and in curing rickets in children. The ethanolic extract of the plant has a potent immune-stimulant activity. It is well known in Ayurveda for its tremendous medicinal significance. The plant is commonly distributed throughout India, especially in hot deciduous forests. The N-terminal sequence of Cryptolepain is unique and shows only little homology to other known serine proteases [6].

\section{Aspartic Proteases EC 3.4.23}

$\nabla$

Aspartic proteases differ from the serine and cysteine peptidases in the way that the nucleophile that attacks the scissile peptide bond is an activated water molecule rather than the nucleophilic side chain of an amino acid. Interestingly, only one enzyme was reported in the literature ( $\bullet$ Table 2 ).

\section{Protease from the latex of Ficus racemosa L.}

Ficus racemosa $\mathrm{L}$. (Moraceae) is a moderate sized to large tree found in all parts of India in moist localities. The proteolytic activity of the enzyme was not inhibited by specific cysteine-, serine- and metalloprotease inhibitors. Pepstatin A a high binding inhibitor specific for aspartic proteases inhibits the enzyme only. Its enzymatic specificity studied using the oxidized B chain of insulin indicates that the protease preferably hydrolyzed peptide bonds C-terminal to glutamate, leucine and phenylalanine [28].

\section{Cysteine Proteases EC 3.4.22}

$\nabla$

41 families of cysteine proteases are recognized until today in which the nucleophile is the sulfhydryl group of a cysteine residue. The catalytic mechanism is similar to that of serine-type peptidases ( Fig. 1) in that the nucleophile and a proton donor/general base are required, and the proton donor in all cysteine peptidases is a histidine residue as in the majority of the serine centered forms. Although there is evidence in some families that a third residue is required to orientate the imidazolium ring of the histidine, a role analogous to that of the essential aspartate seen in some serine peptidases. There are a number of families in which only a catalytic dyad is necessary [8]. The cysteine protease family comprises six major families. Most of the latex cysteine proteases belong to the Papain family (C1). Cysteine proteases of plants play a major role in intracellular and extracellular processes such as development and ripening of fruits [29] as nutritional reserve; degradation of storage protein in germinating seeds [30], [31], activation of proenzymes, and degradation of detective proteins [9], [32]. They are involved in protein maturation, degradation and protein rebuilding in response to various external stimuli and also play a house-keeping function to remove abnormal misfolded proteins [33].They also participate in developmental stages such as morphogenesis and cell biogenesis and senescence, as well as in programmed cell death [34], [35]. In addition they are involved in perception, signalling, and response to biotic and abiotic stress, leading to plant defence [36], [37], [38], [39].

In addition to their important physiological roles, plant cysteine proteases have also received special attention in the food and biotechnology industries owing to their property of being active over a wide range of temperatures and $\mathrm{pHs}$, they also have applications in the pharmaceutical industry for the preparation of drugs, for example, for the debridement of wounds and the prevention of infection burns [39], [40], [41].

\section{Isolation and chemical properties}

The purification methods of latex cysteine proteases are similar to those of serine proteases often including ammonium sulfate or acetone precipitation, column chromatography, gel filtration, affinity chromatography, and hydrophobic interaction chromatography. The molecular weights of latex cysteine proteases are in the range from $21-29 \mathrm{kDa}$. They are very stabile towards $\mathrm{pH}$ ( $3-12$ ) and temperatures (up to $80^{\circ} \mathrm{C}$ ) like the serine latex proteases. Concerning inhibition of proteolytic activity, commonly used inhibitors are iodoacetamide (IAA), p-chloromercury benzoate (PCMB), sodium tetrathionate, mercuric chloride, transepoxysuccinyl-L-leucylamido-(4-guanidino)butane (E-64). The data are listed in $\bullet$ Table 3.

\section{Properties of different cysteine proteases from latex-bearing plants}

Ervatamins A, B, C: Three cysteine proteases purified from the latex of Ervatamia coronaria (Jacq.) Stapf, (Apocynaceae), a flowering plant indigenous to India, have a wide range of medicinally important applications. The latex is cooling and has an anti-inflammatory effect on wounds. Roots rubbed into a paste act as a 
vermicide. The Ervatamins are highly stable over a wide $\mathrm{pH}$ range and other extreme conditions of temperature, denaturants, and organic solvents. They are strongly inhibited by thiolspecific inhibitors (PCMB, iodoacetamide). The N-terminal sequence is similar to that of other cysteine proteases; Ervatamin C has a similarity of $66 \%$ to Ervatamin B and $50 \%$ to Papain. Ervatamin B (ERV-B) and Ervatamin C (ERV-C) have been crystallized at room temperature [42], [43], [44], [45].

Heynein: This protease is purified from the latex of Ervatamia heyneana (Wall.) T. Cooke (Apocynaceae). Similar to the Ervatamins, Heynein is stable at $\mathrm{pH}$ values between 8.5 and 11.5, high temperature (up to $63{ }^{\circ} \mathrm{C}$ ), and strong denaturants. E. heyneana has a wide range of important medicinal applications including anticancerous activities of its root, leaf, and stem extracts in addition to its anti-inflammatory effect on wounds [5].

Funastrains CII, Cl: Funastrains are isolated from the stems of Funastrum clausum (Jacq.) Schlechter [syn. Sarcostemma clausum (Jacq.) Roem. \& Schult, Asclepiadaceae]. The plant is a vine with leaves narrowly linear to broadly elliptic and white to greenish cream flowers. The species is widely distributed from USA to Argentina, and used in popular medicine to kill screw-worm larvae in human flesh by application of a poultice of the leaves, also its latex is used to remove warts [46]. Funastrain CII shows a remarkable stability of its caseinolytic activity after incubation at temperatures as high as $70^{\circ} \mathrm{C}$. The N-terminal sequence of Funastrain CII shows a high degree of homology (80\%) with Asclepain F (Asclepias fruticosa L.) another plant cysteine protease [47].

Morrenains BI, BII: Morrenains BI and BII were purified and characterized from the latex of stems and petiols of Morrenia brachystephana Griseb. (Asclepiadaceae). Morrenain BI is the minor proteolytic component in the latex but shows higher specific activity than Morrenain BII which is the main active fraction. Both enzymes show similar pH profiles and molecular masses but kinetic parameters and $\mathrm{N}$-terminal sequences are quite distinct [48], [49], [50].

Morrenain $\mathrm{O}$ II: Morrenain O II is a proteolytic enzyme present in the latex of Morrenia odorata (Hook et Arn.)Lindley (Asclepiadaceae). The N-terminal sequence of Morrenain OII shows 95\% identity to that of Morrenain BII from Morrenia brachystephana Griseb. [48].

Asclepain $\mathrm{F}$ : This cysteine protease was purified from the latex of the fruits (follicles) of Asclepias fruticosa L., (Asclepiadaceae). A. fruticosa is a small shrub with opposite, lanceolate, and acuminate leaves, white flowers, and light green, inflated, pubescent, latex-containing follicles [51].

Asclepain Cl: Asclepain CI is the major purified protease from latex of stems of 'Scarlet milkweed' Asclepias crussasiva L., (Asclepiadaceae), an erect, evergreen perennial sub-shrub with a woody base and with opposite leaves. The leaves are about $5-$ $15 \mathrm{~cm}$ long, narrowly elliptic, and pointed at both ends. The flowers are arranged in umbels with reflexed five-parted corolla that are brilliant red-purple in color, exposing the crown of five orange-horned hoods. Scarlet milkweed is native to South America but has become a naturalized weed in the tropical and subtropical pastures, fields and distributed areas throughout the world. Asclepain CI shows a high identity with other plant cysteine proteases particularly with Funastrain CII (87\%) and Asclepain F (86\%) [52].

Asclepains A3, B5: Two groups of Asclepains have been isolated from Asclepias syriaca L. (Asclepiadaceae) latex. Both groups are fractionated into 5 components. A representative of each group has been purified. Asclepains A3 and B5 are homogeneous pro- teins with molecular weights of $23 \mathrm{kDa}$ and $21 \mathrm{kDa}$, respectively. Both enzymes are autoprotolytic when active and inhibited by $p$ chloromercury benzoate, iodoacetic acid and sodium tetrathionate. There are notable differences in their amino acid compositions [53].

Asclepain G: Ten Asclepain forms were found to be present in the latex of milkweed Asclepias glaucescens H.B.K. (Asclepiadaceae). Four of them were purified by high performance liquid chromatography on a cation exchange resin and characterized. Asclepains AG3, AG6, AG7 and AG8 were isolated as homogeneous proteins of similar molecular weights and isoelectric points. These forms possess nearly identical secondary structure as judged from their circular dichroism spectra [54].

Asclepain S, Asclepain M: Asclepain S was purified from the latex of Asclepias speciosa Torr. and Asclepain M from the latex of Asclepias mexicana Cav. Both are members of Asclepiadaceae family. There are both inhibited by cysteine-specific inhibitors (e. g., iodoacetic-acid) [55].

Calotrop(a)ins DI, DII, FI, FII: There are at least four cysteine proteases purified from the latex of Calotropis gigantea (L.) Dryand. (Asclepiadaceae). The plant is commonly known as milkweed or swallow-wort and is known for its medicinal properties. The latex is applied to soften the outer skin portion while removing thorns and is also used on fresh cuts to stop bleeding, it has been used as an anti-inflammatory agent in folk medicine [56]. Several tribal people used this latex for easy delivery, abortion and other ailments [57]. Calotropins FI and FII are glycoproteins with a carbohydrate content of $4.04 \%$ and $0.76 \%$, respectively. Calotropins DI and DII are without any carbohydrate content. The crude extract, after removal of gum and ammonium sulfate precipitation, hydrolyzes the $\mathrm{A} \alpha, \mathrm{B} \beta$ and $\gamma$ subunits of human fibrinogen in a dose-dependent manner [58], [59], [60], [61].

Procerain: Procerain is a stable protease isolated from the latex of Calotropis procera (Aiton) Dryand., (Asclepiadaceae) commonly known as Arka in India, and a popular medicinal plant throughout the tropics of Asia and Africa. Ethanolic extracts of the flower of the plant are reported to have anti-microbial, antiinflammatory, antipyretic, analgesic, anticancerous and antimalarial activities. Likewise, water, ethanol, acetone and some other organic solvent extracts of this plant have insecticidal, larvicidal, antibacterial and antiparasitic activities. Procerain retains full activity over a broad range of $\mathrm{pH}(3.0-12.0)$ and temperature up to $70^{\circ} \mathrm{C}$, being stable at very high concentrations of chemical denaturants and organic solvents [32].

Araujiains HI, HII, $\mathbf{H}$ III: Three cysteine proteases purified from the latex of Araujia hortorum Fourn. fruits (Asclepiadaceae). A. hortorum is a South American climbing plant that grows in the south of Brazil, Paraguay, Uruguay and Argentina. The latex has been used in folk medicine as a local application to warts. The $\mathrm{N}$ terminal sequences of Araujiain HI, Araujiain HII and Araujiain HIII show a high degree of homology with other plant cysteine proteases [62], [63].

Philibertain G I: Philibertain G I was purified from the latex of fruits of Philibertia gilliesii Hook. et Arn., (Apocynaceae) a native plant with a wide distribution in subtropical South America. It is the most basic cysteine protease purified from latex. Philibertain GI has an isoelectric point higher than 10.25 . The enzyme shows a higher degree of identity (73\%) with Caricain [64].

Mexicain: Mexicain is a cysteine protease from the latex of fruits of Jacaratia mexicana (A. DC.) [syn. Pileus mexicanus (A. DC.) I.M. Johnst., Caricaceae]. The structure of Mexicain shows the typical Papain-like fold composed of two domains, the $\alpha$-helix rich (L) 
domain and the $\beta$-barrel-like (L) domain. The enzyme is characterized by a high $\mathrm{pH}$ and temperature stability while maintaining a high proteolytic activity. It has a strong sequence identity (73.8\%) to cysteine protease CC-III from Carica candamarcensis Hook f. and to Chymopapain (69.42\%) from Carica papaya L.. Mexicain is strongly inhibited by the specific cysteine protease inhibitor E-64 [39], [65].

Papain: Papain is the proteolytically active constituent in the latex of the tropical papaya fruit, Carica papaya L. (Caricaceae). Papain is the most widely studied member of the cysteine proteinase class of enzymes. Papain exhibits endopeptidase, amidase and esterase activities. The enzyme is produced as an inactive precursor [66], [67] and is located in the plant within the latex of the laticifer system [8]. C. papaya L. has a long tradition in medicinal use. The latex has been used for treatment of warts, corns, and cancer, the roots for piles and yaws, the leave for nervous pain and the fruits for infected wounds, malignant tumors [68]. Since the early $19^{\text {th }}$ century extracts from the papaya plant have been used against parasitic infection and gastrointestinal nematodes like ascarids, tapeworms, whipworms and hookworms, by indigenous people, particularly in tropical countries [69]. Papaincontaining ointments are used in wound debridement to remove necrotic tissue from chronic wounds and burns [70].

Chymopapain: Chymopapain is another proteolytic enzyme in the latex of papaya fruit (Carica papaya L.). The sequence is $58 \%$ identical to Papain, 65\% to Caricain and 70\% to the glycylendopeptidase. Crude preparations in which Chymopapain is the most abundant proteolytic component are used in a number of industrial applications, such as meat tenderization and food processing, and the dehairing of hide in the leather industry [71]. For many years Chymopapain has been used in chemonucleolysis for the treatment of herniated or prolapsed lumbar intervertebral disks. The enzyme is injected directly into the center of the affected disk where it digests the proteoglycan component [72], [73]. The fragmented proteoglycan molecules diffuse from the disk causing a reduction in hydrostatic pressure on the nerve root and thus an easing of pain and disability. The most common adverse reactions associated with chemonucleolysis are due to an allergic response [74]. Because of their allergenicity preparations containing the papaya endopeptidases, particularly powders such as dried papaya latex, should be handled with care [8]. Caricain: Caricain is also a proteolytic enzyme from the latex of Carica papaya L. (Caricaceae). It was first described as papaya peptidase A (Schack) and has also been named as papaya peptidase II, papaya proteinase II and papaya proteinase $\Omega$. The name Caricain was recommended by Nomenclature Committee of the International Union of Biochemistry and Molecular Biology in 1992 [8].

Glycylendopeptidase: Glycylendopeptidase is the fourth proteolytic enzyme in the latex of papaya fruits (Carica papaya L., Caricaceae). The four proteases of Carica papaya L. are synthesized as inactive precursors that convert into mature enzymes within 2 min after wounding the plant when the latex is abruptly expelled [8].

Carica candamarcensis endopeptidases CC: There are at least five endopeptidases in the latex of unripe fruits of the so called mountain papaya Carica candamarcensis Hook f. (Caricaceae). The mountain papaya grows naturally at elevated altitudes (from 1500-2000 m) in various tropical regions of the world. The dried latex exhibits a five- to eight-fold higher proteolytic activity than of Carica papaya L. [8].

Ficain: Ficain is the major proteolytic component in the latex of Ficus glabrata H.B.K. (Moraceae). The latex contains nine compo- nents with proteolytic activity. Ficain is broadly Papain-like in terms of its specificity. The amino acid compositions of Ficain and Papain are similar although Ficain has an additional cysteine residue. The amino acid sequence around the active site shows a great similarity to those around the equivalent site in Papain [8]. Proteolytic fractions from the latex are used for unmasking antigens in serology [75]. The historical interest in Ficain originated from the ability to digest gastrointestinal nematodes. Nevertheless, Ficain has not been adopted widely as a treatment for nematode infection in medicine [8].

Ficain P I: Ficain P I was purified from the latex of fruits of Ficus pumila L. (Ficus repens Hort., Moraceae). The plant is a vine with oblong or elliptic leaves (2-10 cm long), fruits are ovoid, yellow or purple. The enzyme is stable at pH values between $6-11$ and temperatures up to $75^{\circ} \mathrm{C}$. There are two other proteolytic active fractions eluting from the column which have not been further characterized [76].

Protease from the latex of Ficus hispida L.f.: Ficus hispida L.f. (Moraceae) is a small tree grown throughout India and in some other tropical countries and the latex of this plant is the source of this proteolytic enzyme. After injury the plant exudes a milky and sticky latex that changes its color immediately to brown. Almost all parts of the plant are used in the traditional system of Indian medicine for treatment of ulcers, complications in bile secretion, psoriasis, anemia, piles, jaundice, hemorrhage of the nose and mouth, diseases of blood, and as antidysenteric, purgative and emetic agents [77].

\section{Other Plants with Proteolytic Activity in the Latex} $\nabla$

- Table 4 shows plants which show proteolytic activity in their lattices but the classification to one of the protease families is not possible until now because of the lack of biochemical studies.

Nevertheless, some of them are rather well characterized (marked with*). The proteolytic enzyme in the latex of Euphorbia amygdaloides L. (Euphorbiaceace) was purified after ammonium sulfate precipitation and ion exchange chromatography on a CM-cellulose column, the molecular mass is $54 \mathrm{kDa}$ and the optimum temperature and $\mathrm{pH}$ conditions are $60^{\circ} \mathrm{C}$ and $\mathrm{pH} 5$, respectively (azocasein as substrate), it was tested for its milk clotting activity and the use in cheese production [78]. Curcain is the protease purified from the latex of Jatropha curcas L. (Euphorbiaceae), a perennial hedge plant grown in India and other tropical countries commonly known as Bagbherenda. The seeds are used as a purgative and the root bark is used in external application for sores; tender twigs are used for cleaning teeth; the latex is useful in the treatment of scabies, eczema and ringworm; the leaves are used in the form of a decoction and cataplasma to the breast as a lactagogue. The optimum conditions for the activity of Curcain are a temperature around 45 $60{ }^{\circ} \mathrm{C}$ and a pH 5.6-6.0 (gelatin or casein as substrates). The molecular mass is $22 \mathrm{kDa}$. It was purified by acetone precipitation, mixed solvent precipitation, ammonium sulfate precipitation, ion exchange chromatography on a CMcellulose column, and gel filtration with Sephadex G-200 [79], [80].

Tabernamontain was isolated from the latex of green fruits from Tabernaemontana grandiflora (Jacq.) Miers (Apocynaceae). The proteolytic activity is ten times stronger than that of Papain and it digests living intestinal parasites [81]. 
Table 4 Other plants with proteolytic activity in the latex

\begin{tabular}{|c|c|c|c|c|c|c|c|c|c|}
\hline $\begin{array}{l}\text { Family } \\
\text { Anacardiaceae }\end{array}$ & Ref. & $\begin{array}{l}\text { Family } \\
\text { Apocynaceae }\end{array}$ & Ref. & $\begin{array}{l}\text { Family } \\
\text { Caricaceae }\end{array}$ & Ref. & $\begin{array}{l}\text { Family } \\
\text { Euphorbiaceae }\end{array}$ & Ref. & $\begin{array}{l}\text { Family } \\
\text { Moraceae }\end{array}$ & Ref. \\
\hline \multirow[t]{18}{*}{$\begin{array}{l}\text { Mangifera indica } \\
\text { L. }\end{array}$} & [87] & $\begin{array}{l}\text { Holarrhena anti- } \\
\text { dysenterica (L.) } \\
\text { Wall. Ex A. DC. }\end{array}$ & [88] & $\begin{array}{l}\text { Vasconcellea x } \\
\text { heilbornii V.M. } \\
\text { Badillo }\end{array}$ & [90] & $\begin{array}{l}\text { Euphorbia } \\
\text { amygdaloides L.* }\end{array}$ & [78] & $\begin{array}{l}\text { Brosimum } \\
\text { alicastrum Sw. }\end{array}$ & [96] \\
\hline & & $\begin{array}{l}\text { Plumeria acutifo- } \\
\text { lia (Ait) Wood- } \\
\text { soon }\end{array}$ & [88] & $\begin{array}{l}\text { Vasconcellea } \\
\text { monoica (Desf.) } \\
\text { A. DC. }\end{array}$ & [90] & $\begin{array}{l}\text { Euphorbia } \\
\text { cerifera Alc.* }\end{array}$ & [91] & $\begin{array}{l}\text { Broussonetia } \\
\text { papyrifera Vent. }\end{array}$ & [96] \\
\hline & & $\begin{array}{l}\text { Pulmeria obtusi- } \\
\text { folia L. }\end{array}$ & [88] & $\begin{array}{l}\text { Vasconcellea } \\
\text { stipulata } \\
\text { (V.M. Badillo) } \\
\text { V.M. Badillo }\end{array}$ & [90] & $\begin{array}{l}\text { Euphorbia coeru- } \\
\text { lescens Haw. }\end{array}$ & [92] & $\begin{array}{l}\text { Ficus } \\
\text { benghalensis L. }\end{array}$ & [88] \\
\hline & & $\begin{array}{l}\text { Tabernaemontana } \\
\text { divaricata L. }\end{array}$ & [88] & & & Euphorbia esula L. & [93] & Ficus benjamina L. & [96] \\
\hline & & $\begin{array}{l}\text { Tabernaemontana } \\
\text { grandiflora* Jacq. } \\
\text { Miers }\end{array}$ & [81] & & & $\begin{array}{l}\text { Euphorbia helio- } \\
\text { scopia L. }\end{array}$ & [93] & $\begin{array}{l}\text { Ficus brevifolia } \\
\text { Nutt. }\end{array}$ & [96] \\
\hline & & $\begin{array}{l}\text { Thevetia nerifolia } \\
\text { Jur. Exsteud. }\end{array}$ & [88] & & & Euphorbia hirta L. & [88] & $\begin{array}{l}\text { Ficus carica L. var. } \\
\text { Kadota }\end{array}$ & [97] \\
\hline & & $\begin{array}{l}\text { Vallaris heynei } \\
\text { Sprung }\end{array}$ & [88] & & & $\begin{array}{l}\text { Euphorbia } \\
\text { royleana Boiss. }\end{array}$ & [94] & Ficus carica ssp. & [98] \\
\hline & & $\begin{array}{l}\text { Wirghtia tinctoria } \\
\text { R.Br. }\end{array}$ & [89] & & & $\begin{array}{l}\text { Euphorbia } \\
\text { splendens Bojer } \\
\text { ex Hook. }\end{array}$ & [92] & $\begin{array}{l}\text { Ficus crassinervia } \\
\text { Desf. Ex } \\
\text { Willdenow }\end{array}$ & [96] \\
\hline & & & & & & $\begin{array}{l}\text { Euphorbia } \\
\text { trigona Haw. }\end{array}$ & [92] & $\begin{array}{l}\text { Ficus glabella } \\
\text { Blume }\end{array}$ & [96] \\
\hline & & & & & & Hura crepitans L.* & [95] & $\begin{array}{l}\text { Ficus glomerata } \\
\text { Roxb. }\end{array}$ & [88] \\
\hline & & & & & & $\begin{array}{l}\text { Jatropha curcas } \\
\text { L.* }\end{array}$ & $\begin{array}{l}{[79]} \\
{[80]}\end{array}$ & $\begin{array}{l}\text { Ficus laurifolia } \\
\text { Hort. ex Lam. }\end{array}$ & [99] \\
\hline & & & & & & $\begin{array}{l}\text { Jatropha } \\
\text { gossypifolia L. }\end{array}$ & [94] & $\begin{array}{l}\text { Ficus nitida } \\
\text { Thunb. }\end{array}$ & [96] \\
\hline & & & & & & $\begin{array}{l}\text { Jatropha } \\
\text { podagrica Hook. }\end{array}$ & [88] & $\begin{array}{l}\text { Ficus nota } \\
\text { (Blanco) Merr. }\end{array}$ & [96] \\
\hline & & & & & & & & Ficus religiosa L. & [88] \\
\hline & & & & & & & & $\begin{array}{l}\text { Ficus spragueana } \\
\text { Mildbr. \& Burret }\end{array}$ & [96] \\
\hline & & & & & & & & 37 Ficus ssp. & [100] \\
\hline & & & & & & & & Morus alba L. & [93] \\
\hline & & & & & & & & Morus nigra L. & [96] \\
\hline
\end{tabular}

\section{Conclusion}

\section{$\nabla$}

The latex of some plant families such as Apocynaceae, Asclepiadaceae, Asteraceae, Caricaceae, Convolvulaceae, Euphorbiaceae, and Moraceae contains endopeptidases. Nearly half of the commercially available enzymes are also proteases, frequently used in food processing, tenderization of meat, brewing, cheese elaboration, bread manufacture, and in the leather and textile industries. Besides, some proteases have also been used as model systems for studies on their structure-function relationship, and in the protein folding problem [5], [32], [43]. Proteolytic enzymes from plant latex have also received special attention in the pharmaceutical industry and biotechnology due to their property of being active over wide ranges of temperature and $\mathrm{pH}$. The determination of the type of latex proteases might also be a scientific aid in chemotaxonomy for the classification of Euphorbiaceae, Asteraceae, and Convolvulaceae because only serine proteases are found to date in these families. In Apocynaceae and Caricaceae there are only cysteine proteases and in Asclepiadaceae both cysteine and serine proteases have been detected. Otherwise members of the Moraceae contain serine, cysteine and also the only isolated aspartatic protease where the enzymatic mechanism is totally different compared with that of cysteine and serine proteases.

Because of the importance of proteases in signal transduction via protease-activated receptors (PARs), this type of enzyme might be interesting also for pharmacology and toxicology. PARs are a family of G-protein-coupled receptors that signal in response to extracellular proteases. There are four PAR subtypes encoded in the mammalian species activated by trypsin-like serine proteases. PARs are involved in the regulation of hemostasis and thrombosis, as well as in inflammatory and proliferative responses triggered by vascular injury [82]. PARs are widely distributed throughout the human body and involved in many physiological and pathological processes, e.g., PARs play a role in the pathophysiology for atopic and allergic diseases. Activation of PAR-2 triggers both pro- and anti-inflammatory activities by regulating monocyte recruitment/activation in inflamed tissue [83]. So the effects of latex proteases might be discussed within the activation of protease activated receptors. In history and traditional medicine, most of the described latex proteases are known for the ability to digest gastrointestinal parasites and for their anti-in- 
flammatory activity but are also feared for their allergenicity. A systematic research in this field has not been reported until now, thus the search for biological active proteases is still going on.

\section{References}

1 Golovkin BN. Latex and proteolytic enzymes in plants. Byulleten Glavnogo Botanicheskogo Sada 2006; 191: 157-60

2 Radauer C, Breiteneder $\mathrm{H}$. Evolutionary biology of plant food allergens. J Allergy Clin Immunol 2007; 120: 518-25

3 Lewinsohn TM. The geographical distribution of plant latex. Chemoecology 1991; 2: 64-8

4 Liggieri C, Arribére MC, Trejo SA, Canals F, Avilés FX, Priolo NS. Purification and biochemical characterization of Asclepain c I from the latex of Asclepias curassavica L. Protein J 2004; 23: 403 -11

5 Patel BK, Jagannadham MV. A high cysteine containing thiol porteinase from the latex of Ervatamia heyneana: purification and comparison with Ervatamin B and C from Ervatamia coronaria. J Agric Food Chem 2003: 51: 6326-34

6 Pande M, Dubey VK, Yadav SC, Jagannadham MV. A novel serine protease Cryptolepain from Cryptolepis buchanani: purification and biochemical characterization. J Agric Food Chem 2006; 54: 10141 - 50

7 Antão CM, Malcata FX. Plant serine proteases: biochemical, physiological and molecular features. Plant Physiol Biochem 2005; 43: 637- 50

8 Barrett AJ, Rawlings ND, Woessner JF. Handbook of Proteolytic Enzymes New York: Academic Press; 1998

9 Rudenskaya GN, Bogdanova EA, Revina LP, Golovkin BN, Stepanov VM. Macluralisin - a serine proteinase from fruits of Maclura pomifera (Raf.) Schneid. Planta 1995; 196: 174-9

10 Rudenskaya GN, Bogacheva AM, Preusser A, Kuznetsova AV, Dunaevsky YE, Golovkin BN et al. Taraxalisin - a serine proteinase from dandelion Taraxacum officinale Webb s. 1. FEBS Lett 1998; 437: 237-40

11 Menon M, Vithayathil PJ, Raju SM, Ramadoss CS. Isolation and characterization of proteolytic enzymes from the latex of Synadenium grantii Hook, "f". Plant Sci 2002; 163: 131 - 9

12 Arima K, Uchikoba T, Yonezawa H, Shimada M, Kaneda M. Cucumisinlike protease from the latex of Euphorbia supina. Phytochemistry 2000; 53: $639-44$

13 Lynn KR, Clevette-Radford NA. Isolation and characterisation of Euphorbain 1, a proteinase from the latex of Euphorbia lathyris. Biochim Biophys Acta 1983; 746: $154-9$

14 Lennox FG, Ellis WJ. Euphorbain, a protease occurring in the latex of the weed Euphorbia lathyris. Biochem J 1945; 39: 465-70

15 Lynn KR, Clevette-Radford NA. Three serine proteases from the latex of Euphorbia cyparissias. Phytochemistry 1985; 24 : $925-8$

16 Lynn KR, Clevette-Radford NA. Euphorbain p, a serine protease from Euphorbia pulcherrima. Phytochemistry 1984; 23: $682-3$

17 Lynn KR, Clevette-Radford NA. Isolation and characterization of proteases from Euphorbia lactea and Euphorbia lactea cristata. Phytochemistry 1986; $25: 807-10$

18 Lynn KR, Clevette-Radford NA. Four serine proteases from the latex of Euphorbia tirucalli. Can J Biochem Cell Biol; 1985; 63: 1093-6

19 Shimada M, Uchikoba T, Yonezawa H, Arima K, Kaneda M. Isolation and characterization of a Cucumisin-like serine protease from the latex of Euphorbia pseudochamaesyce Fisch. J Biochem Mol Biol Biophys 2000; 4: $223-31$

20 Yadav SC, Pande M, Jagannadham MV. Highly stable glycosylated serine protease from the medicinal plant Euphorbia milii. Phytochemistry 2006; 67: 1414-26

21 Lynn KR, Clevette-Radford NA. Hevains: serine-centred proteases from the latex of Hevea brasiliensis. Phytochemistry 1986; 25: 2279-82

22 Lynn KR, Clevette-Radford NA. Purification and characterization of Hevain, a serine protease from Hevea brasiliensis. Phytochemistry 1984; 23: $963-4$

23 Lynn KR, Clevette-Radford NA. Two proteases from the latex of Elaeophobia drupifera. Phytochemistry 1985; 24: $2843-5$

24 Lynn KR. Parthenain, a protease from Parthenium argentatum. Phytochemistry 1988; 27: 1987 - 91

25 Prasad KMR, Virupaksha TK. Purification and characterization of a protease from jackfruit latex. Phytochemistry 1990; 29: 1763-6

26 Patel AK, Singh VK, Jagannadham MV. Carnein, a serine protease from noxious plant weed Ipomoea carnea (Morning Glory). J Agric Food Chem 2007; 55: 5809-18

27 Lynn KR, Clevette-Radford NA. Ficin e, a serine-centred protease from Ficus elastica. Phytochemistry 1986; 25: 1559-61
28 Devaraj KB, Gwoda LR, Prakash V. An unusual thermostable aspartic protease from the latex of Ficus racemosa (L.). Phytochemistry 2008; 69: $647-55$

29 Brady CJ. Fruit ripening. Annu Rev Plant Physiol 1985; 38: 155 - 78

30 Kembhavi AA, Buttle DJ, Knight CG, Barrett AJ. The two cysteine endopeptidases of legume seeds: purification and characterization by use of specific fluorometric assay. Arch Biochem Biophys 1993; 303: 208 13

31 Taylor RM, Cuming AC. Purification of an endoproteinase that digests the wheat 'Em' protein in vitro, and determination of its cleavage sites. FEBS Lett 1993; 331: $76-80$

32 Dubey VK, Jagannadham MV. Procerain, a stable cysteine protease from the latex of Calotropis procera. Phytochemistry 2003; 62: 1057-71

33 Wiśniewski K, Zagdańska B. Genotype-dependent proteolytic response of spring wheat to water deficiency. J Exp Bot 2001; 52: 187-96

34 Solomon M, Belenghi B, Delledonne M, Menachem E, Levine A. The involvement of cysteine proteases and protease inhibitor genes in the regulation of programmed cell death in plants. Plant Cell 1999; 11: $431-44$

35 Palma JM, Sandalio LM, Corpas FJ, Romero-Puertas MC, McCarthy I, del Rio LA. Plant proteases, protein degradation, and oxidative stress: role of peroxisomes. Plant Physiol Biochem 2002; 40: 521 - 30

36 Konno K, Hirayama C, Nakamura M, Tateishi K, Tamura Y, Hattori M et al. Papain protects papaya trees from herbivorous insects: role of cysteine proteases in latex. Plant J 2004; 37: 370-8

37 Grudkowska M, Zagdańska B. Multifunctional role of plant cysteine proteinases. Acta Biochem Pol 2004; 51: 609-24

38 van der Hoorn RA, Jones JD. The plant proteolytic machinery and its role in defence. Curr Opin Plant Biol 2004; 7: 400-7

39 Gavira JA, González-Ramírez LA, Oliver-Salvador MC, Soriano-García M, García-Ruiz JM. Structure of the Mexicain-E-64 complex and comparison with other cysteine proteases of the Papain family. Acta Crystallogr 2007; D63: 555-63

40 Starley IF, Mohammed P, Schneider G, Bickler SW. The treatment of paediatric burns using topical papaya. Burns 1999; 25: 636-9

41 Ford CN, Reinhard ER, Yeh D, Syrek D, De Las Morenas A, Bergman SB et al. Interim analysis of a prospective, randomized trial of vacuum-assisted closure versus the healthpoint system in the management of pressure ulcers. Ann Plast Surg 2002; 49: 55 -61

42 Nallamsetty S, Kundu S, Jagannadham MV. Purification and biochemical characterization of a highly active cysteine protease Ervatamin A from the latex of Ervatamia coronaria. J Protein Chem 2003; 22: 1 -13

43 Kundu S, Sundd M, Jagannadham MV. Purification and characterization of a stable cysteine protease Ervatamin B, with two disulfide bridges, from the latex of Ervatamia coronaria. J Agric Food Chem 2000; 48: $171-9$

44 Thakurta PG, Biswas S, Chakrabarti C, Sundd M, Jagannadham MV, Dattagupta JK. Structural basis of the unusual stability and substrate specifity of Ervatamin C, a plant cysteine protease from Ervatamia coronaria. Biochemistry 2004; 43: $1532-40$

45 Kundu S, Sundd M, Jagannadham MV. Structural characterization of a highly stable cysteine protease Ervatamin C. Biochem Biophys Res Commun 1999; 264: 635-42

46 Morcelle SR, Caffini NO, Priolo N. Proteolytic properties of Funastrum clausum latex. Fitoterapia 2004; 75: 480-93

47 Morcelle SR, Trejo SA, Canals F, Avilés FX, Priolo NS. Funastrain cII: A cysteine endopeptidase purified from the latex of Funastrum clausum. Protein J 2004; 23: 3

48 Cavalli SV, Cortadi A, Arribére MC, Conforti P, Caffini NO, Priolo NS. Comparison of two cysteine endopeptidases from latices of Morrenia brachystephana Griseb. and Morrenia ordorata (Hook et Arn.) Lindley (Asclepiadaceae). Biol Chem 2001; 382: 879-83

49 Cavalli SV, Arribére MC, Cortadi A, Caffini NO, Priolo NS. Morrenain bI, a Papain-like endopeptidase from the latex of Morrenia brachystephana Griseb. (Asclepiadaceae). J Protein Chem 2003; 22: 15-22

50 Arribére MC, Cortadi A, Gattuso MA, Bettiol MP, Priolo NS, Caffini NO. Comparison of Asclepiadaceae latex protease and characterization of Morrenia brachystephana Griseb. cysteine peptidases. Phytochem Anal 1998; 9: 267-73

51 Trejo SA, López LM, Cimino CV, Caffini NO, Natalucci CL. Purification and characterization of a new plant endopeptidase isolated from latex of Asclepias fruticosa L. (Asclepiadaceae). J Protein Chem 2001; 20: $469-77$ 
52 Liggieri C, Arribére MC, Trejo SA, Canals F, Avilés FX, Priolo NS. Purification and biochemical characterization of Asclepain c I from the latex of Asclepias curassavica L. Protein J 2004; 23: 403 - 11

53 Brockbank WJ, Lynn KR. Purification and preliminary characterization of two Asclepains from the latex of Asclepias syriaca L. (Milkweed). Biochim Biophys Acta 1979; 578: 13-22

54 Tablero M, Arreguin R, Arreguin B, Soriano M, Sánchez RI, Romero Rodriguez A et al. Purification and characterization of multiple forms of Asclepain g from Asclepias glaucescens H.B.K. Plant Sci 1991; 74: 7 15

55 Winnick T, Davis AR, Greenberg DM. Physicochemical properties of the proteolytic enzyme from the latex of the milkweed, Asclepias speciosa Torr. some comparisons with other proteases J Gen Physiol; 1939: $275-88,289-300$

56 Dahanukar SA, Kulkarni RA, Rege NN. Pharmacology of medicinal plants and natural products. Indian J Pharmacol 2000; 32: 81 - 118

57 Bhuyan DK. Herbal drugs used by the tribal people of Lohit district of Arunachal Pradesh for abortion and easy delivery - a report. Adv Plant Sci 1994; 7: 97 - 202

58 Sengupta A, Bhattacharya D, Pal G, Sinha NK. Comparative studies on Calotropins DI and DII from the latex of Calotropis gigantea. Arch Biochem Biophys 1984; 232: 17-25

59 Rajesh $R$, Raghavendra Gowda $C D$, Nataraju A, Dhananjaya $B L$, Kemparaju K, Vishwanath BS. Procoagulant activity of Calotropis gigantea latex associated with fibrin(ogen)olytic activity. Toxicon 2005; 46: 84-92

60 Pal G, Sinha NK. Isolation, crystallization, and properties of Calotropins DI and DII from Calotropis gigantea. Arch Biochem Biophys 1980; 202: $321-9$

61 Abraham KI, Joshi PN. Isolation of calotropain FI. J Chromatogr 1979; 168: $284-9$

62 Priolo N, Morcelle del Valle S, Arribére MC, López L, Caffini N. Isolation and characterization of a cysteine protease from the latex of Araujia hortorum fruits. J Protein Chem 2000; 19: 39-49

63 Obregón WD, Arribére MC, Morcelle del Valle S, Liggieri C, Caffini N, Priolo $N$. Two new cysteine endopeptidases obtained from the latex of Araujia hortorum fruits. J Protein Chem 2001; 20: 317-25

64 Sequeiros C, Torres MJ, Trejo SA, Esteves JL, Natalucci CL, López LM. Philibertain $\mathrm{g} I$, the most basic cysteine endopeptidase purified from the latex of Philibertia gilliesii Hook. et Arn. (Apocynaceae). Protein J 2005; $24: 7-8$

65 Oliver-Salvador MC, González-Ramírez LA, Gavira JA, Soriano-García M, García-Ruiz JM. Purification, crystallization and preliminary X-ray analysis of mexicain. Acta Crystallogr 2004; 60: 2058 -60

66 Cohen LW, Coghlan VM, Dihel LC. Cloning and sequencing of Papainencoding cDNA. Gene 1986; 48: 219-27

67 Vernet T, Tessier DC, Richardson C, Laliberté F, Khouri HE, Bell AW et al. Secretion of functional Papain precursor from insect cells. Requirement for N-glycosylation of the pro-region. J Biol Chem 1990; 265 : $16661-6$

68 Starley IF, Mohammed P, Schneider G, Bickler SW. The treatment of paediatric burns using topical papaya. Burns 1999; 25: 636-9

69 Berger J, Asenjo CF. Anthelmintic activity of crystalline Papain. Science 1940; $91: 387-8$

70 Yaakobi T, Cohen-Hadar N, Yaron H, Hirszowicz E, Simantov Y, Bass A et al. Wound debridement by continuous streaming of proteolytic enzyme solution: Effects on experimental chronic wound model in porcine. Wounds - A compendium of clinical research and practice 2007; 19: $192-200$

71 Caygill JC. Sulphydryl plant proteases. Enzyme Microb Technol 1979; 1: $233-42$

72 Buttle DJ, Abrahamson M, Barrett AJ. The biochemistry of the action of chymopapain in relief of sciatica. Spine 1986; 11: 688-94

73 Dekeyser PM, Buttle DJ, Devreese B, Van Beeumen J, Demeester J, Lauwers A. Kinetic constants for the hydrolysis of aggrecan by the papaya proteinases and their relevance for chemonucleolysis. Arch Biochem Biophys 1995; 320: 375 -9

74 Dando PM, Sharp SL, Buttle DJ, Barrett AJ. Immunoglobulin E antibodies to papaya proteinases and their relevance to chemonucleolysis. Spine 1995; 20: $981-5$
75 Buttle DJ. Affinity chromatography of cysteine peptidases. Methods Enzymol 1994; 244: 639-48

76 Perelló M, Arribére MC, Caffini NO, Priolo NS. Proteolytic enzymes from the latex of Ficus pumila L. (Moraceae). Acta Farm Bonaerense 2000; 19: $257-62$

77 Chetia D, Nath LK, Dutta SK. Extraction, purification and physicochemical properties of a proteolytic enzyme from the latex of Ficus hispida Linn. Indian J Pharm Sci 1999; 61: 29-33

78 Demir Y, Alayli A, Yildirim S, Demir N. Identification of protease from Euphorbia amygdaloides latex and its use in cheese production. Prep Biochem Biotechnol 2005; 35: 291 -9

79 Nath LK, Dutta SK. Extraction and study of certain physico-chemical properties of a new proteolytic enzyme from the latex of Jatropha curcas Linn. Indian J Pharm Sci 1988; 50: 125 - 7

80 Nath LK, Dutta SK. Extraction and purification of Curcain, a protease from the latex of Jatropha curcas Linn. J Pharm Pharmacol 1991; 43: $111-4$

$81 \mathrm{Jaffe}$ WG. A new vegetable proteolytic enzyme of the papain class. Rev Bras Biol 1943; 3: 149-57

82 Arora P, Ricks TK, Trejo J. Protease-activated receptor signalling, endocytic sorting and dysregulation in cancer. J Cell Sci 2007; 120: 921 - 8

83 Fiorucci S, Distrutti E. Proteinase-activated receptors (PARs) and immune function. Drug Dev Res 2003; 60: 65-70

84 Chakrabarti C, Biswas S, Kundu S, Sundd M, Jagannadham MV, Dattagupta JK. Crystallization and preliminary X-ray analysis of Ervatamin B and C, two thiol proteases from Ervatamia coronaria. Acta Crystallogr D Biol Crystallogr 1999; D55: 1074-5

85 De Moraes MG, Termignoni C, Salas C. Biochemical characterization of a new cysteine endopeptidase from Carica candarmarcensis L. Plant Sci 1994; 102: $11-8$

86 Sugiura M, Sasaki M. Studies on proteinases from Ficus carica var. Horaishi. V. Purification and properties of a sugar-containing proteinase (Ficin S). Biochim Biophys Acta 1974; 350: $38-47$

87 John KS, Bhat SG, Prasada Rao UJ. Biochemical characterization of sap (latex) of a few Indian mango varieties. Phytochemistry 2003; 62: 13 9

88 Chary MP, Reddy SM. Protease activity of some latex bearing plants. Nat Acad Sci Lett 1983; 6: 183-4

89 Rajesh R, Shivaprasad HV, Gowda CD, Nataraju A, Dhananjaya BL, Vishwanath BS. Comparative study on plant latex proteases and their involvement in hemostasis: A special emphasis on clot inducing and dissolving properties. Planta Med 2007; 73: 1061 - 7

90 Kyndt T, Van Damme EJM, Van Beeumen J, Gheysen G. Purification and characterization of the cysteine proteinases in the latex of Vasconcellea ssp. FEBS J 2007; 274: 451 - 62

91 Castaneda M, Balcazar MR, Gavarron FF. The proteolytic activity of the latex of Euphorbia cereifera. Anales Escuela Nacl Cienc Biol 1943; 3: $65-72$

92 Lynn KR, Clevette-Radford NA. Biochemical properties of latices from the Euphorbiaceae. Phytochemistry 1987; 26: 939-44

93 Gonashvili SG, Gonashvili MS. Proteolytic enzymes of some Georgian plants. Rastitel'nye Resursy 1968; 4: 356-65

94 Singh D, Singh A. Biochemical alteration in freshwater fish Channa punctatus due to latices of Euphorbia royleana and Jatropha gossypifolia. Environ Toxicol Pharmacol 2002; 12: 129-36

95 Jaffé WG. Hurain, a new plant protease from Hura crepitans. J Biol Chem 1943; 149: 1 - 7

96 Robbins BH, Lamson PD. Further studies of the proteolytic enzyme content of the latex from fig and related trees. J Biol Chem 1934; 6: $725-8$

97 Kramer DE, Whitaker JR. Ficus enzymes II. Properties of the proteolytic enzymes from the latex of Ficus carica variety kadota. J Biol Chem 1964; 239: $2178-83$

98 Sgarbieri VC, Gupte SM, Kramer DE, Whitaker JR. Ficus enzymes I. Separation of the proteolytic enzymes of Ficus carica and Ficus glabrata latices. J Biol Chem 1964; 239: 2170-7

99 Robbins BH. A proteolytic enzyme in ficin, the anthelmintic principle of leche de Higueron. J Biol Chem 1930; 87: $251-7$

100 Williams DC, Sgarbieri VC, Whitaker JR. Proteolytic activity in the genus Ficus. Plant Physiol 1968; 43: 1083-8 